\title{
TRADISI WUKU TAUN SEBAGAI BENTUK INTEGRASI AGAMA ISLAM DENGAN BUDAYA SUNDA PADA MASYARAKAT ADAT CIKONDANG
}

\author{
Deni Miharja \\ UIN Sunan Gunung Djati Bandung \\ email: miharjadeni@yahoo.co.id
}

\begin{abstract}
This article write starts from some phenomena of the relation between religions and local cultures. Such relation is interesting to do research that interpretations of the relation between religion and local cultures to certain societies are various. The interaction between Islam and local cultures also undergoes variuos form of relation. Variety of the form of relation between Islam and local cultures in a society depends upon their understanding and interpretation of Islamic teachings itself. One of the forms of relation between Islam and local cultures can be found in traditional society of Cikondang. The form of relation between Islam and local cultures was occurred in traditional society in Cikondang tends to be the form of integration wich certain pattern. Therefore, the focus of this writer article is to describe relation between Islam and Sundanese cultures in form of integration with wuku taun. Based on data of research the tradisional society of Cikondang represents the part of Sundanese society in wich all of them are muslims. This goes hand in hand with the statement that Islam is Sunda and Sunda is Islam. Sundanese people are Muslims before Islam comes to Sundanese society.
\end{abstract}

Tulisan artikel ini berangkat dari fenomena hubungan agama dengan budaya lokal. Dimana hubungan agama dengan budaya lokal pada suatu masyarakat, mengalami bentuk hubungan yang beragam. Begitu pun hubungan agama Islam dengan budaya lokal mengalami bentuk hubungan yang beragam pula. Beragamnya bentuk hubungan agama Islam dengan budaya lokal pada suatu masyarakat tergantung dari penghayatan terhadap ajaran Islam itu sendiri. 
Bentuk hubungan agama Islam dengan budaya lokal bisa ditemukan salah satunya pada masyarakat adat Cikondang. Bentuk hubungan yang terjadi antara Islam dengan budaya Sunda pada masyarakat adat Cikondang cenderung dalam bentuk integrasi dengan pola tertentu, sehingga fokus penulisan artikel ini adalah untuk mengungkap hubungan agama Islam dengan budaya Sunda dalam bentuk integrasi melalui tradisi wuku taun. Berdasarkan data yang diperoleh, masyarakat Cikondang merepresentasikan sebagian masyarakat Sunda yang seluruhnya beragama Islam. Hal ini tentu sejalan dengan beberapa pernyataan yang menyebutkan Islam itu Sunda dan Sunda itu Islam, orang Sunda sudah Islam sebelum Islam.

Keywords: Wuku Taun Tradition, Sundanese Culture, Islamic Tradition

\section{Pendahuluan}

Masyarakat Cikondang dikenal sebagai etnis Sunda yang dikategorikan sebagai komunitas adat, dan seluruhnya beragama Islam. Identifikasi ini bisa saja berhubungan dengan berbagai ungkapan yang menyebutkan pola hubungan Islam dengan budaya Sunda yang begitu dekat, seperti ungkapan "Islam teh Sunda, Sunda teh Islam" atau "Urang Sunda mah geus Islam samemeh Islam" yang artinya adalah "Orang Sunda sudah Islam sebelum Islam masuk ke wilayah Tatar Sunda” (Praja, 2005: 131).

Apabila dicermati secara seksama, maka ada yang menarik dari bentuk ungkapan tersebut, yaitu terjalinnya hubungan agama Islam dengan budaya Sunda yang harmonis yang menunjukan adanya hubungan dalam bentuk integrasi. Fenomena tersebut menunjukan bahwa agama dan kebudayaan ada secara bersamaan pada suatu masyarakat. Tentu keberadaannya tidak bisa dipahami secara sepihak, tetapi harus dipahami secara utuh terhadap adanya proses dialektik agama dengan kebudayaan pada masyarakat itu sendiri, serta adanya unsur-unsur yang saling berhubungan secara fungsional .

Agama dan kebudayaan merupakan dua hal yang bisa ditemukan keberadaan fungsinya pada masyarakat. Oleh karena itu, ketika berbicara agama dan kebudayaan, bisa melihat aplikasi fungsinya dalam wujud sistem budaya dan juga dalam bentuk tradisi ritual atau upacara keagamaan yang nyata-nyata bisa mengandung nilai agama dan kebudayaan secara bersamaan.

Kajian yang menyebutkan beragamnya pola hubungan Islam dengan budaya lokal. Salah satunya, Tarekat dalam Islam: Spritualitas Masyarakat Modern, menyatakan bahwa masyarakat Jawa Barat cenderung Muslim karena pendekatan yang dipakainya adalah pendekatan sosiologi, dengan melihat akar sosio kultural masyarakat, menemukan bahwa masyarakat Jawa Barat 
masa kini cenderung muslim (Kahmad, 2002: 95) Ini berarti bahwa masa diantara masa lalu yang kebatinan dan kondisi masa kini yang Islam di duga kuat telah terjadi Islamisasi masyarakat Jawa Barat secara besar-besaran, sehingga kondisi riil masyarakat Jawa Barat secara temporal menjadi Muslim (Rozak, 2005: 298-299).

Buku yang berjudul tentang Teologi Kebatinan Sunda: Kajian Antropologi Agama tentang Aliran Kebatinan Perjalanan yang diangkat dari disertasi berjudul "Teologi Kebatinan Perjalanan: Studi Antropologi Agama", dalam salah satu kesimpulannya menyebutkan bahwa masyarakat Jawa Barat cenderung kebatinan (Rozak, 2005: 299). Fakta riil menunjukkan bahwa secara kultural, kondisi lingkungan, kultur, filsafat hidup, dan nilai-nilai spritual etnik sunda, cenderung kebatinan. Demikian pula, fakta riil secara sosiologis menunjukkan bahwa kondisi sosial dan struktur sosial etnik Sunda, meskipun diduga, secara arkeologis, berpangkal dari kultur tasawuf Islam, setelah berakumulasi dengan nilai-nilai kultur etnik Sunda juga cenderung masih kental kebatinan.

Tulisan ini ingin mengungkap tentang tradisi wuku taun sebagai bentuk integrasi Agama Islam dengan budaya Sunda pada masyarakat adat Cikondang Desa Lamajang Kecamatan Pangalengan Kabupaten Bandung.

\section{Hubungan Agama Islam dengan Budaya Sunda}

Latar belakang tulisan ini adalah lahir karena adanya hubungan agama dengan kebudayaan pada suatu masyarakat. Hubungan agama dengan kebudayaan terjadi secara berkesinambungan dan dalam waktu yang lama, sehingga hasil dari adanya hubungan agama dengan kebudayaan akan menghasilkan suatu pola hubungan yang berlainan dan dalam bentuk tertentu.

Kajian tentang kearifan lokal sendiri sebenarnya tidak terlepas dari persoalan agama dan kebudayaan yang tumbuh pada suatu masyarakat. Tak ada masyarakat yang dapat hidup tanpa sesuatu seperti sains dan sesuatu seperti agama, semua kebudayaan selalu membutuhkan konsepsi pikiran dari sains dan "construct of heart" dari agama. Seorang sarjana tanpa komitmen agama tidak akan berhasil dalam usaha menteoritisasikan agama, karena ia akan jatuh pada reduksionisme (Pritchard, 2001: 378).

Agama dalam kedudukannya sebagai sistem budaya sebenarnya adalah bagian dari kebudayaan, karena kebudayaan itu memiliki tiga wujud, yakni: sistem budaya, sistem sosial dan kebudayaan fisik (artefak). Agama sebagai sistem budaya sangat bisa berbeda dengan agama sebagai doktrin yang tertulis dalam kitab-kitab suci karena ia mengalami interelasi dialektis dengan kebudayaan 
dan masyarakatnya. Jika agama telah menjadi bagian dari kebudayaan maka secara sosial adalah konteks makna yang dipahami bersama, terdiri atas struktur arti yang mapan, dimana orang-orang melakukan hal-hal semacam itu sebagai konspirasi yang jelas untuk bergabung didalamnya, merasakan penghinaan bersama dan menjawabnya bersama (Geertz, 2001: 409). Dalam konteks ini, maka hubungan Islam dengan kebudayaan Sunda sama halnya dengan hubungan Islam dengan kebudayaan Jawa atau agama lokal lainnya adalah agama dalam kedudukannya sebagai sistem budaya yang menjadi world view masyarakatnya. Diakui atau tidak, ia terus hidup dan berkembang dalam masyarakat seiring dengan dinamika sosial dan kulturual.

Kemudian perlu dijelaskan bahwa bagaimana sebenarnya proses terjadinya agama lokal atau sistem kultural itu dalam realitas sosial. Salah satu usaha untuk mendekati masalah ini adalah melalui analisis konstruksi sosial, di mana realitas sosial dipandang sebagai diciptakan oleh individu. Individu adalah manusia bebas yang melakukan hubungan antar manusia satu dengan yang lain. Individu menjadi penentu dalam dunia sosial yang dikonstruksi berdasarkan kehendaknya. Individu bukanlah korban fakta sosial, namun sebagai mesin produksi sekaligus reproduksi yang kreatif dalam mengkonstruksi dunia sosialnya (Basrowi dkk., 2002: 194). Namun, kehendak individu sendiri tentunya tidak mungkin terlepas sepenuhnya dari sistem keyakinan dari ajaran agama yang dianutnya. Perilaku individu dan sosial digerakkan oleh kekuatan dari dalam yang didasarkan pada nilai-nilai ajaran agama yang telah menginternalisasi sebelumnya (Kahmad, 2000: 53).

Eksistensi manusia itu pada pokoknya dan pada akhirnya adalah aktivitas yang mengeksternalisasi. Selama eksternalisasi tersebut manusia mencurahkan makna ke dalam realitas. Agama, dalam hal ini agama sebagai fakta sosial, merupakan jangkauan terjauh dari ekstrenalisasi diri manusia, dari peresapan makna-maknanya sendiri ke dalam realitas. Agama berarti, bahwa tatanan manusia itu diproyeksikan ke dalam totalitas kedirian. Dengan kata lain, agama adalah usaha berani untuk membayangkan adanya keseluruhan semesta sebagai bernilai manusiawi. Karena itu agama memainkan peranan sangat strategis dalam usaha manusia membangun dunia (Berger, 1990: 34-35).

Dalam kerangka ini, agama dimaksudkan sebagai makna-makna tertinggi yang dicapai oleh puncak eksternalisasi manusia dan menyerap dalam realitas. Agama dalam perspektif ini lebih dekat pada fakta sosial "yang hidup" di masyarakat daripada sekedar konsep-konsep "yang mati”, lebih dekat pada aspek "praktis" ketimbang "teoritis". Maka dengan konsep ini bisa dijelaskan 
bagaimana hubungan Islam dengan kebudayaan Sunda bisa terbangun sebagai suatu sistem kultural pada masyarakat Sunda.

Banyak penulis yang menyebutkan bahwa Islam dengan Sunda ibarat gula dengan manisnya (jiga gula jeung peueutna), karena dalam kenyataannya perkembangan Islam di tatar Sunda sealur dengan local genium masyarakat Sunda itu sendiri. Dalam perkembangannya, Islam lebih mudah berinteraksi dengan sistem nilai yang berlaku saat itu. Karena ciri khas dari agama ini adalah memberikan kebudayaannya berkembang sesuai dinamika (hands off) (Tochija, 2005: ix). Islam Sunda atau Sunda Islam dapat dikatakan "dua-duaning atunggal" dan sepertinya sudah sangat kental satu sama lainnya, sebab dalam beberapa hal ajaran-ajaran atau adat istiadat Sunda adalah juga ajaran Islam (Suryaman, 2005 : xii).

Terdapat dua asumsi yang menyebabkan Islam dengan mudah menjadi bagian dari kehidupan orang Sunda. Pertama, Islam yang datang dan diterima oleh masyarakat Sunda merupakan sebentuk ajaran yang mudah dicerna dan dipahami sesederhana karakter budaya orang Sunda itu sendiri. Kedua, kebudayaan yang membungkus ajaran Islam tersebut merupakan kebudayaan yang mudah bersinergis dengan budaya Sunda. Oleh karena itu, ketika proses Islamisasi di Tata Sunda Islam menyebar dengan mudah, maka Islam secara tidak langsung membentuk jati diri kesundaan orang sunda terintegralkan secara natural dalam perilaku keseharian sekaligus menjadi identitas permanen orang Sunda (Kahmad, 2006 : 322).

Hubungan antara agama Islam dengan kebudayaan Sunda bisa terdiri atas beberapa bentuk, yang terkena hukum perubahan. Pertama, kemungkinan terjadi konflik antara agama Islam dengan kebudayaan Sunda, baik secara tersembunyi (latent) maupun secara nyata (manifest), yang berpangkal dari inti kebudayaan yang berbeda. Kedua, kemungkinan terjadi koeksistensi atau adhesi antara agama Islam dengan kebudayaan Sunda tanpa saling intervensi dan mengganggu. Ketiga, kemungkinan terjadi integrasi atau kohesi, baik dalam wujud perembesan agama Islam ke dalam kebudayaan Sunda, atau adaptasi kebudayaan Sunda terhadap agama Islam, baik secara simbolis maupun substansial (Bisri, 2005: 264).

\section{Tradisi Wuku Taun sebagai Bentuk Integrasi Agama Islam dengan Budaya Sunda pada Masyarakat Adat Cikondang}

Istilah tradisi harus dipahami sebagai sebuah kebiasaan yang terjadi pada masyarakat. Tradisi biasanya secara umum dimaksudkan untuk menunjuk 
kepada suatu nilai, norma dan adat-istiadat lama yang kini masih diterima, diakui bahkan, dipertahankan oleh masyarakat tertentu. Kata tradisi atau "tradition" (bahasa Inggris), berarti segala sesuatu seperti adat, kebiasan, ajaran dan sebagainya yang turun temurun dari nenek moyang dan masih dijalankan oleh masyarakat (Poerwadarminta, 1982: 1088).

Tradisi adalah kebiasaan sosial yang diturunkan dari satu generasi ke generasi lainnya melalui proses sosialisasi. Tardisi menentukan nilai-nilai dan moral masyarakat, karena tradisi merupakan aturan-aturan tentang hal apa yang benar dan hal apa yang salah menurut warga masyarakat. Konsep tradisi itu meliputi pandangan dunia (world view) yang menyangkut kepercayaan tentang masalah kehidupan dan kematian serta peristiwa alam dan makhluknya; atau konsep tradisi itu berkaitan dengan sistem kepercayaan, nilai-nilai dan cara serta pola berpikir masyarakat (Garna, 1996: 186).

Istilah tradisi terbagi menjadi tradisi besar dan tradisi kecil, atau tradisi feodal dan tradisi rakyat. Konsep tradisi besar atau bangsawan itu dikaitkan dengan cara hidup warga masyarakat kalangan atas (istana) dari suatu peradaban, cara hidup itu diwarisi dan diturunkan dari satu generasi ke generasi lainnya. Sedangkan konsep tradisi rakyat digunakan sebagai konsep yang berlawanan dengan tradisi bangsawan atau tradisi besar, yang menjelaskan tentang kebudayaan rakyat biasa dalam suatu kebudayaan tertentu, tradisi rakyat itu seringkali menyerap tradisi besar setelah mengalami proses penyesuaian (Redfield, 1961: 186).

Pengertian tersebut dapat disimpulkan bahwa pengertian tradisi adalah segala sesuatu tata kelakuan atau kebiasaan lama, yang diwariskan secara turun temurun, kemudian diakui, diamalkan, dipelihara, bahkan dipertahankan oleh masyarakat tertentu, sehingga menjadi satu kesatuan menjadi tak terpisahkan dari pola kehidupan sehari-hari.

Tradisi dalam pengertian di atas mempunyai kriteria bahwa ia di ciptakan melalui tingkah laku manusia, pemikiran serta imajinasinya. Sedangkan yang ditransmisikan adalah pola-pola atau citra dari tingkah laku pemikiran dan imajinasi tadi, yang di dalamnya termasuk kepercayaan, serta norma-norma, aturan anjuran serta larangan dalam menjalankan kembali pola-pola tersebut.

Kehidupan masyarakat sunda yang ada di Jawa Barat pada umumnya tidak terlepas dari bermacam-macam upacara syukuran, lengkap dengan tatacara masing-masing. Perbuatan mereka bukan hanya kebiasaan semata, 
bahkan menjadi suatu peranan hidup yang harus dilakukan dan di taati oleh mereka. Tuntutan hidup yang harus dan ditaati ini adalah hasil dari warisan dari para leluhur.

Warisan leluhur ini biasanya mereka sebut dengan istilah tradisi atau adat-istiadat. Dalam tiap pengalaman serta kepercayaan yang menifestasinya beragam sekali, tradisi memainkan peranan yang sangat penting bagi masyarakat. Mereka melihat lingkungan dan alam sernya selalu dipandang dengan kacamata tradisi. Bahkan saja dalam kehidupan sehari-hari, tetapi juga dalam agama, ilmu dan filsafat. Konsep seseorang yang benar dan salah, indah dan buruk, bernilai dan tak bernilai, wajar dan tak wajar, selalu berhubungan dengan kebiasaan tradisional tertentu.

Suatu tradisi biasanya dipertahankan oleh masyarakat tertentu, karena mereka menganggap bahwa tradisi yang mereka pertahankan, baik secara objektif dan subjektif adalah suatu yang bermakna, berarti dan bermanfaat bagi kehidupannya. Makna tradisi bagi masyarakat adalah sebagai wadah ekspresi masyarakat (Bawani, 1993: 36-42).

Tradisi yang diciptakan oleh suatu masyarakat pada dasarnya merupakan alat pengikat. Manusia adalah mahluk sosial, sehingga hidup berkelompok merupakan suatu keharusan, karena tidak ada orang yang mampu memenuhi kebutuhan sendiri. Oleh karena itu selalu ada upaya untuk menegakkan dan membina kelompok, dengan harapan agar menjadi kokoh dan menjaga kelestariannya. Adapun cara yang ditempuh dengan cara pengikat, termasuk yang berwujud tradisi.

Dari sini dapat dilihat bahwa tradisi yang berwujud cara-cara seseorang melakukan sesuatu, kebiasaan-kebiasaan, tata kelakuan dan adat istiadat yang dimiliki oleh suatu kelompok (masyarakat) merupakan suatu alat pengikat kelompok. Tanpa adanya norma yang dapat mengikat seluruh anggota, suatu kelompok tidak akan punya identitas yang khas, dan kelestarianpun menjadi terancam.

Kebiasaan dan norma-norma dapat menyangkut berbagai aspek kehidupan, misalnya sosial, ekonomi, politik, ilmu pengetahuan dan tehnik, seni filsafat, dan agama. Tradisi yang berwujud dalam bentuk kebiasaan dan norma-norma kehidupan suatu kelompok, biasanya tercermin dalam keseragaman dalam melakaukan aktifitas di bidang sosial, ekonomi, politik dan sebagainya. Dengan demikian, akan semakin rekatlah ikatan keanggotaan dalam kelompok tersebut (Gazalba 1968: 48-49).

Selanjutnya tradisi ini juga bisa menjadi benteng pertahanan. Kelompok 
tradisional, atau kelompok tertentu yang dengan gigih mempertahankan serta melestarikan sebagai tradisi masa lalu dan turun-temurun, mereka sedang menghadapi tantangan berat dan besar, yaitu dari mordenisasi.

Kecenderungan dan upaya untuk mempertahankan, melestarikan tradisi secara turun-temurun, terkadang dengan dalih bahwa sudah sepantasnya mempertahankan tradisi leluhur, sesungguhnya dimaksudkan untuk melindungi diri dari kelompoknya dari bermacam-macam sentuhan budaya modern yang pada umumnya ingkar terhadap orang yang mereka pertahankan. Oleh sebab itu tradisi sangat bermakna menjadi benteng pertahanan.

Tradisi dapat sebagai penjaga keseimbangan lahir dan batin. Manusia terdiri atas jasmani dan rohani, oleh karenanya maka butuh perpaduan yang bersifat lahir dan batin. Perpaduan antara lahir dan batin, ditujukan untuk mencapai tujuan kehidupan, yaitu kebahagian atau ketentraman.

Tradisi keagamaan yang dilaksanakan oleh masyarakat adat Cikondang merupakan bentuk upacara keagamaan. Upacara adalah suatu kerangka pergerakan dan perkataan yang penuh gaya dan mempunyai keterangan yang berhati-hati yang dapat dikerjakan oleh yang khusus dipilih untuk melakukannya. Upacara biasanya mempunyai makna-makna simbolik dan digunakan untuk mendramatisir perkara-perkara yang dianggap penting yang memerlukan penggunaan perasaan tenang serta rasa hormat (Roucek, dkk., 1984: 30). Dari segi bahasa, upacara didefinisikan sebagai tindakan agama atau upacara merupakan agama dalam tindakan (Dhavamony, 1995: 176).

Upacara atau ibadat yang dilakukan suku-suku primitif tidak hanya berfungsi sebagai penangkis dari pada mara-bahaya, tetapi sering untuk menambahkan hati (Peursen, 1988: 35). Pendapat lain mengatakan kebanyakan dari perbuatan juga dapat disebut sebagai upacara, baik hal yang mengerjakan tanah ladangnya maupun pernikahan dan dalam upacara-upacara tersebut mereka mempunyai mithe sendiri yang merupakan naskah atau sekenario dari perbuatan-perbuatan yang harus dilakukan dalam upacara-upacara itu (Honig, 1988: 25-26)

Unsur-unsur yang biasa ada dalam pelaksanaan ritual upacara keagamaan, yaitu: Pertama, adanya dunia ghoib yang dihadapi manusia dengan berbagai macam perasaan, seperti rasa cinta, hormat, tetapi juga ada rasa takut, ngeri, atau campur dari berbagai macam perasaan tadi. Tiap upacara keagamaan dapat terbagi ke dalam empat komponen, yaitu: tempat upacara, waktu upacara, benda atau alat upacara, peserta dan pemimpin upacara.

Kedua, jalannya upacara. Dalam jalannya upacara keagamaan ini, sering 
dibawa alat-alat keramat seperti patung dewa-dewa, lambang-lambang, totem, benda-benda pusaka dan benda sakti lainnya. Alat-alat tersebut mempunyai maksud mengusir makhluk halus, hantu, dan hal yang menyebabkan penyakit dan bencana. Biasanya penyampaian melalui nyanyian kramat, manteramantera atau tepuk sorak dan teriak bunyian-bunyian yang keras dan berbagai macam lainnya. Selain itu dengan berdo'a berupa ucapan dari keinginan manusia yang diminta dari para leluhur, dan juga upacara-upacara hormat serta pujian kepada leluhur, diiringi dengan gerak dan sikap tubuh sebagai rasa rendah dan hormat kepada leluhur. Bertitik tolak pada ritual upacaraupacara yang dilakukan oleh masyarakat adat Cikondang dengan landasan melestarikan adat tradisi yang sudah di bawa sejak dahulu oleh leluhurnya, maka kebudayaan hasil integrasi Islam dengan budaya Sunda pada masyarakat adat Cikondang bisa ditemukan pada konsep pandangan hidup, wuku taun dan ritual keagamaan lainnya.

Dalam melihat integrasi Islam dengan budaya Sunda, tentu yang harus dipahami adalah bagaimana nilai-nilai ajaran Islam itu masuk dan bersentuhan dengan kebudayaan Sunda itu sendiri. Nilai-nilai ajaran Islam pada masyarakat adat Cikondang lebih cenderung diintegrasikan dengan tradisi yang sudah dibangun sejak awal. Proses integrasi Islam dengan budaya Sunda terjadi, ketika masyarakat adat Cikondang tetap setia melestarikan nilai-nilai padangan hidup tersebut dalam setiap kegiatan yang rutin dilaksanakan. Baik melalui kegiatan formal di sekolah, di mesjid bahkan dalam kegiatan non formal melalui ritual keagamaan yang sengaja dilaksanakan secara terjadwal dengan baik.

Cikondang adalah nama sebuah kampung di Lereng Gunung Tilu yang nyaman dan damai. Secara turun-temurun, masyarakat Kampung Cikondang masih teguh memegang adat istiadat leluhur, sehingga kearifan yang diwariskan secara turun temurun, menjadikan wilayah setempat mampu membuat alam sekitarnya lestari. Meskipun Cikondang telah berubah rupa sejak kebakaran besar tahun 1942 yang melanda kampung ini, namun nilai-nilai tradisi itu masih dipertahankan. Beberapa bangunan adat berupa rumah dengan konsep rumah Sunda nampak masih berdiri kokoh dan terpelihara dengan baik. Inilah yang menjadikan identitas adat disandang oleh kampung Cikondang (Dasyah, 2013: 71).

Dalam hal tradisi, masyarakat adat Cikondang memiliki tradisi wuku taun. Wuku taun adalah sebuah tradisi adat yang telah dilaksanakan kurang lebih dua abad oleh masyarakat Cikondang. Pada kenyataannya, terdapat unsur-unsur kebudayaan lokal yang berbaur dengan unsur agama. Kebudayaan 
lokal yang dimaksud adalah animisme yang memang sudah berkembang sejak awal di masyarakat kita, kemudian unsur agamanya adalah dari unsur Hindu dan Islam.

Tradisi wuku taun termasuk kategori adat, karena wajib dilaksanakan setiap tahunnya. Upacara ini berkaitan dengan upacara taun baru Islam yaitu tahun baru hijriah. Diperingati setiap tanggal 15 Muharam. Istilah seleh taun, mapag taun dapat diartikan "seleh taun" maksudnya pergantian taun sedang "mapag taun" artinya menyambut atau menyongsong Tahun Baru. Istilah "seleh" identik dengan "seren" berarti serah terima atau melepas tahun lalu dengan segala kenangannya dan menyambut tahun baru agar lebih baik dari tahun yang sebelumnya. upacara adat ini dilakukan dengan secara besar-besaran, baik oleh penduduk Cikondang khususnya maupun Desa Lamajang pada umumnya.

Ada tiga tujuan dalam rangka pelaksanaan upacara seleh taun mapag taun (musiman) yaitu sebagai upacara untuk mengungkapakan rasa terima kasih dan rasa syukur. Ungkapan rasa terima kasih diungkapkan pada karuhun (leluhur), yang telah membuka kawasan Cikondang dari hutan menjadi permukiman untuk anak cucunya sampai sekarang. Adapun rasa syukur di tunjukan kepada Allah SWT. Yang telah memberikan segalanya kepada mereka, baik itu mata pencaharian, tempat tinggal yang subur, ketentraman kedamaian, dan sebagainya (Rif`ati, dkk., 2002 : 16).

Tujuan lain diadakannya wuku taun ini adalah untuk berdo'a memohon keselamatan kepada Yang Maha Kuasa bagi seluruh warga khususnya masyarakat kampung Cikondang, umumnya semua warga yang berada disekitarnya. Mereka meyakini, jika upacara ini tidak dilaksanakan akan mendapat malapetaka bagi warga masyarakat setempat khususnya masyarakat Cikondang. Oleh karena itu dari tahun ke tahun upacara tersebut selalu dilaksanakan secara periodik. Menurut penuturan salah seorang tokoh disana abah Ilin Dasyah:"Upacara ini belum pernah tidak dilaksanakan oleh masyarakat Cikondang" (Wawancara, Cikondang: 21 Juli 2013).

Masyarakat Cikondang dari generasi awal sampai generasi sekarang tetap patuh menjalankan ritual upacara wuku taun. Upacara wuku taun dilaksanakan di Bumi Adat. Pertimbangannya karena upacara ini berasal dari leluhur yang menempati bumi adat secara turun-temurun. Demikian juga, setiap kegiatan yang berhubungan dengan upacara tidak boleh keluar dari Bumi Adat; mulai persiapan membuat bahan makanan dan perelengkapannya, memasak, sampai ijab kabul. Begitu pula beras, beserta bumbu dan perlengkapan tumpeng harus 
berasal dari hutan, sawah, dan ladang keramat yang merupakan kekayaan bumi adat. Satu bentuk pelestarian tradisi leluhur yang paling menonjol di Kampung Cikondang adalah pelaksanaan upacara adat wuku taun. Upacara adat ini dilakukan sebagai bentuk syukur atas anugerah Yang Maha Kuasa karena telah memberikan hasil bumi yang melimpah untuk menghidupi mereka sepanjang tahun. Selain bentuk syukur, wuku taun juga dimaksudkan sebagai ritual menyambut tahun baru dengan do'a semoga setahun ke depan diberikan keselamatan dan perlindungan.

Tradisi wuku taun selalu jatuh pada 15 Muharam. Namun sejak tanggal 1 Muharam, kesibukan warga telah tampak di sana-sini. mereka bergotong royong menumbuk padi yang kelak dijadikan bahan nasi tumpeng. Padi yang sebelumnya disimpan di lumbung tersebut merupakan hasil panen tahun lalu dari sawah keramat yang menjadi kekayaan adat.

Kaum wanita yang bertugas menumbuk padi terdiri atas lima atau enam orang dengan ketentuan, mereka tidak sedang haid. Pakaiannya khusus, dilengkapi karembong atau kain yang diselendangkan yang biasanya digunakan untuk menggendong bayi dan kepalanya ditutup kerudung. Kegiatan menyambut upacara Seren Mapag Taun dari hari ke hari makin meningkat. Selain menyiapkan beras untuk bahan pembuat nasi tumpeng, kaum wanita membuat opak dan makanan khas masyarakat Kampung Cikondang.

Kaum pria secara bergotong royong menyiapkan kayu bakar dan daun pisang yang harus diambil dari kaki Gunung Tilu. Kelak, daun-daun tersebut dijadikan bahan untuk berbagai macam wadah penganan dan lauk-pauk yang digunakan pada puncak upacara yang diselenggarakan tanggal 15 Muharam. Seperti diungkap kuncen Bumi Adat Cikondang, Anom Samsa dan Ilin Dasyah, upacara wuku taun telah dilaksanakan lebih dari tiga abad (Wawancara, Cikondang: 21 Juli 2013).

Terhitung sejak leluhur pertama mereka tinggal di kawasan hutan Gunung Tilu. Setiap tahun, tanpa diundang, ratusan orang keturunan masyarakat adat Cikondang ikut terlibat dalam upacara tersebut. Upacara dimulai dengan penyembelihan ayam untuk dimasukkan dalam tumpeng padi ladang dan padi sawah. Masyarakat di rumah masing-masing membuat tumpeng berisi ayam. Sebagian masyarakat lainnya dengan sukarela bekerja di rumah adat, mempersiapkan tumpeng, lauk-pauk, dan 12 kue tradisi antara lain ampengan ketan, opak putih dan merah, wajit, ketan, pisang, dan kelontong.

Masyarakat yang membuat tumpeng di rumah-rumah akan menyerahkan tumpengnya ke rumah adat dan pekerja di rumah adat akan membalasnya 
dengan tumpeng lain yang lebih lengkap. Upacara ditutup sore hari dengan doa bersama sebagai tanda syukur atas rezeki tahun lalu. Peserta upacara pun tak hanya masyarakat adat Cikondang saja, tapi juga warga dari luar kampung.

Menjelang tengah hari, puluhan nasi tumpeng yang berasal dari rumahrumah penduduk dibawa ke rumah adat. Kelak, setelah Kuncen membacakan ijab kabul yang menandai puncak acara tersebut, nasi tumpeng berikut laukpauknya dibagikan kembali kepada masyarakat. Sekitar seratus meter arah selatan rumah adat terdapat tiga makam, yaitu makam Anom atau Uwa Idil, Mak Akung, dan Mak Mpuh. Tempat tersebut dipercaya pula sebagai tempat ngahyang atau menghilangnya leluhur mereka yang menjadi penduduk pertama dan sekaligus pendiri Kampung Cikondang.

"Inti dari upacara ini adalah mengucap syukur kepada Tuhan Yang Maha Esa dan para leluhur Kampung Cikondang yang berperan bagi kesejahteraan dan keselamatan kampung mereka. Nasi tumpeng merupakan simbol dari rasa syukur tersebut. Dari pembuatan hingga pembagian tumpeng pengiring yang sebanyak 100 buah, merupakan gambaran rasa gotong royong dan kebersamaan warga masyarakat.

Pada hakikatnya, wuku taun bukanlah pesta perayaan semata. Dengan melaksanakan upacara adat tersebut, warga seolah membuka dan membaca kembali sebuah buku yang memuat sejarah Kampung Cikondang. "Tahun ini kami telah melaksanakan wuku taun untuk yang ke-304. Ini artinya, upacara ini sudah berlangsung sejak tiga abad lalu," ungkap Abah Ilin.

Tumpeng lulugu yang berjumlah tiga itu masing-masing terdiri dari tiga macam beras yang berbeda, yaitu beras padi, beras padi huma, dan beras ketan. Abah Ilin menuturkan, pada awalnya masyarakat Kampung Cikondang bertani dalam bentuk huma. Sejak sistem irigasi masuk pada awal tahun 1900, sebagian masyarakat Kampung Cikondang beralih ke cara bertanam sawah dengan siklus tiga kali panen dalam setahun (Wawancara, Cikondang: 21 Juli 2013).

Selain sebagai bukti historis, penggunaan makanan berbahan dasar beras ini menegaskan tentang keterikatan masyarakat Kampung Cikondang dengan alam sekitar. Mayoritas penduduk Kampung Cikondang bermata pencaharian petani.

Bahan lain yang digunakan sebagai pelengkap juga berasal dari beras. Di samping tumpeng, terdapat 12 jenis makanan ringan pengiring, seperti peuyeum, dodol, wajit, angleng, upuntir, ampeyang, borondong, lontong, opak merah dan opak putih. Pengiring yang nonberas hanya tebu dan buah pisang.

Berdasarkan uraian tersebut, maka bisa disebutkan bahwa tradisi wuku taun merupakan bentuk integrasi agama Islam dengan budaya Sunda 
yang dilaksanakan setiap menyambut bulan Muharam setiap tahunnya oleh masyarakat adat Cikondang.

\section{Simpulan}

Berdasarkan gambaran dari tradisi wuku taun tersebut, maka bisa disimpulkan, sebagai berikut:

Pertama, tradisi wuku taun merupakan bentuk kebudayaan hasil integrasi agama Islam dengan budaya Sunda yang diciptakan dan dilaksanakan oleh masyarakat adat Cikondang dalam menyambut datangnya bulan Muharam. Makna yang terdapat pada tradisi tersebut, pada hakikatnya merupakan media ungkapan rasa syukur kepada Allah SWT yang telah melimpahkan segala rizki dan karunia-Nya.

Kedua, bisa disebutkan bahwa ada kecenderungan masyarakat Cikondang dipengaruhi oleh agama Islam, sehingga terjadilah proses integrasi agama Islam dengan masyarakat Cikondang dalam bentuk tradisi wuku taun.

Ketiga, kebudayaan hasil integrasi tersebut, dilaksanakan dan dilestarikan oleh masyarakat adat Cikondang sampai saat ini. Walaupun dalam prakteknya tidak semua warga mengikuti tradisi tersebut secara rutin. Terjadinya proses dialektik agama Islam dengan budaya Sunda pada masyarakat adat Cikondang sudah berjalan cukup lama, maka kemungkinan untuk kuatnya agama Islam berbaur dengan budaya Sunda, tidak bisa dihindari.

Keempat, masyarakat Cikondang dikategorikan sebagai komunitas masyarakat adat, karena sampai saat ini masih berpegang teguh terhadap tradisi leluhurnya dan seluruhnya beragama Islam. Artinya disini terjadi integrasi Islam dengan budaya Sunda dalam pola-pola tertentu. Setelah dilakukan pengkajian secara mendalam, maka pola integrasi sinkretik cenderung pada masyarakat yang masih berpegang teguh terhadap tradisi leluhurnya (Cikondang dalam), sehingga pemahaman keagamaan mereka dikategorikan tradisional dengan sebutan Islam sinkretik. Sedangkan pola integrasi akulturatif cenderung pada masyarakat yang tidak terikat dengan tradisi leluhur (Cikondang luar), sehingga pemahaman keagamaan mereka dikategorikan modern dengan sebutan Islam akulturatif.

\section{Daftar Pustaka}

Bawani, Imam. 1993. Tradisionalisme dalam Pendidikan Islam. Surabaya: Al Ikhlas.

Basrowi dan Sukidin. 2002. Metode Penelitian Kualitatif; Perspektif Mikro. 
Surabaya: Insan Cendekia.

Berger, Peter L. 1990. The Sacred Canopy. Terjemahan oleh Hartono. Jakarta: LP3ES.

Bisri, Cik Hasan et al. (eds.). 2005. Pergumulan Islam Dengan Kebudayaan Lokal di Tatar Sunda. Cetakan ke-1. Bandung: Kaki Langit.

Dasyah, Ilin. 2013. Sekelumit tentang Keberadaan Rumah Adat Cikondang. Kumpulan tulisan berupa Makalah. Cikondang.

Dhavamony, Mariasuasi. 1995. Fenomenologi Agama. Yogyakarta: Kanisius.

Garna, Judistira K. 1996. Ilmu-Ilmu Sosial Dasar-Konsep-Posisi. Bandung: Pascasarjana Unpad.

Gazalba, Sidi. 1968. Pengantar Kebudayaan Sebagai Ilmu. Cetakan ke-1. Jakarta: Pustaka Antara.

Geertz, Clifford. 2001. "Agama sebagai Sistem Budaya”, dalam Daniel L. Pals, Seven Theories of Religion. Terjemahan oleh Ali Noer Zaman. Yogyakarta: Qalam.

Honig, A.G. 1988. Ilmu Agama. Jakarta: BPK Gunung Mulia.

Kahmad, Dadang. 2000. Sosiologi Agama. Bandung: Rosdakarya.

Kahmad, Dadang. 2002. Tarekat dalam Islam: Spritualitas Masyarakat Modern. Bandung: Pustaka Setia.

Kahmad, Dadang. 2006. "Agama Islam dan Budaya Sunda”, dalam Ajip Rosidi, Edi S. Ekajati dan A. Chaedar Alwasilah (Penyunting). Konferensi Internasional Budaya Sunda Jilid I. Cetakan ke-1, Bandung: Kiblat Buku Utama.

Peursen, Van. 1988. Strategi Kebudayaan. Yogyakarta: Kanisius.

Praja, Juhaya S. (ed.). 2005. "Hukum Islam dalam Tradisi dan Budaya Masyarakat Sunda”, dalam Pergumulan Islam Dengan Kebudayaan Lokal di Tatar Sunda. Cetakan ke-1. Bandung: Kaki Langit.

Pritchard, E.E.Evans. 2001. "Construct of The Heart" Masyarakat dalam Daniel L. Pals, Seven Theories of Religion. Terjemahan oleh Ali Noer Zaman.Yogyakarta: Qalam. 
Poerwadarminta, WJS. 1982. Kamus Umum Bahasa Indonesia. Cetakan ke-6. Jakarta: Balai Pustaka.

Redfiled, Robert. 1961. The Little Community and Peasant Society and Culture. Chicago: Chicago University Press.

Rif `ati, Heni Fazria dan Sucipto, Toto 2002. Kampung Adat dan Rumah adat di Jawa Barat. Bandung: Disbudpar Jabar.

Roucek, Joseph S \& Warren, Roland L. 1984. Pengantar Sosiologi. Terjemahan Sahat Simamora. Jakarta: Bina Aksara.

Rozak, Abdul. 2005. Teologi Kebatinan Sunda. Bandung: Kiblat Buku Utama.

Suryaman, Tata Gautama. 2005. dalam pengantar Pergumulan Islam dengan Kebudayaan Lokal di Tatar Sunda, Bandung: Kaki Langit.

Tochija, Itoc. 2005. dalam pengantar Pergumulan Islam dengan Kebudayaan Lokal di Tatar Sunda. Bandung: Kaki Langit. 